\title{
French Catheter Gauge
}

National Cancer Institute

\section{Source}

National Cancer Institute. French Catheter Gauge. NCI Thesaurus. Code C101680.

A number representing the outer diameter of a catheter where each integer represents

$1 / 3$ of a millimeter. 